\title{
Galaicodytes caurelensis gen. n., sp. n., the first troglobitic species of Platynini (Coleoptera: Carabidae: Pterostichinae) from the western Palaearctic region
}

\author{
VICENTE M. ORTUÑO ${ }^{1}$ and José M. SALGADO² \\ ${ }^{1}$ Animal Biology Department, Alcalá University, 28871 Alcalá de Henares, Madrid, Spain; e-mail: ildotre@mad.servicom.es \\ ${ }^{2}$ Animal Biology Department, León University, 24071 León, Spain; e-mail: dbajsc@isidoro.unileon.es
}

Key words. Coleoptera, Carabidae, Pterostichinae, Platynini, new genus, new species, western Palaearctic region, Spain, cave

\begin{abstract}
This study describes Galaicodytes (gen. n.) caurelensis ( $\mathrm{sp} . \mathrm{n}$.) which was captured in a limestone cave in the lower Cambric of NW Spain. It is the first known cave-dwelling Platynini in the western Palaearctic region and shows unique morphological adaptations to cave life. The taxonomic position is based on comprehensive character analysis, including external anatomical, male genitalic, and female genitalic and reproductive tract characters. Certain problems concerning its taxonomic position in relation to other genera are discussed and different ecologic and biogeographic aspects are analysed.
\end{abstract}

\section{INTRODUCTION}

After several biospeleological expeditions in the Cantabrian region (Salgado, 1979, 1984, 1993, 1994, 1995) over the past 20 years, explorations in different karstic areas of the Sierra del Caurel, Lugo, NW Spain began in September 1997 (Fig. 1). The main objective was to carry out a series of samplings in caves which would give us an insight into troglobitic fauna in a biospeleologically unknown area. Although close to the Cantabrian karst, the area is well isolated, as demonstrated by the presence of such troglobitic fauna as Leonesiella bergidi (Salgado, 1983) (Coleoptera: Cholevidae) and Domene (Lathromene) bergidi Salgado \& Outerelo, 1991 (Coleoptera: Staphylinidae). However, the most surprising fact was the capture of 3 specimens of a blind depigmented carabid belonging to the tribe Platynini presenting other characteristics than those typical of eucavernicolous carabids. When evaluated as a whole these characteristics make this particular carabid a rather unusual platynine. We thus propose a new genus for the unknown species which will be described below.

The tribe Platynini is widely distributed throughout the world and it includes a large number of species. However, there are certain doubts about its real phylogenetic relationship. There are only 10 genera of this tribe in the Iberian Penninsula (the number of Iberian species appears in brackets): Olisthopus Dejean, 1828, (5 species); Agonum Bonelli, 1819 (13 species belonging to the subgenus Agonum s. str. and 3 species belonging to the subgenus Europhilus Chaudoir, 1859); Batenus Motschulsky, 1864 (1 species); Platynus Bonelli, 1810 (1 species); Anchomenus Bonelli, 1819 (= Anchodemus Motschulsky, 1864; see Liebherr, 1991) (2 species); Oxypselaphus Chaudoir, 1843 (monospecific); Paranchus Lindroth, 1974 (monospecific) and Cardiomera Bassi, 1834 (monospecific). It should be pointed out that unlike other carabid groups (Trechini and Sphodrini), this tribe has shown less of a cave-dwelling tendency and has few underground colonizers (Casale et al., 1998). Until now, hypogeous Platynini have been found outside the Palaearctic region, whilst the Sphodrini include a large number of underground species in the Palaearctic region (except for Japan). The present discovery represents the first hypogeous Platynini in the western Palaearctic region.

Hypogeous Platynini already known in Asia (Japan and Taiwan) are: Ja ana Uéno, 1955 and some species belonging to Jujiroa Uéno, 1952. In Oceania, three interesting hypogeous taxa have been described from Papua-New Guinea: Speagonum mirabile Moore, 1977 Gastragonum caecum Moore, 1977 and Trogloagonum novaehiberniae Casale, 1982; and two belonging to the genus Atelothrus Sharp, 1903, A. aaae Liebherr \& Samuelson, 1992 and $A$. howarti Liebherr \& Samuelson, 1992, have been located in Hawaii. Finally, the American continent also has hypogeous Platynini: Some species of the genera Rhadine LeConte, 1848 and Mexisphodrus Barr, 1965, Tepuydites auyanensis Monguzzi \& Trezzi, 1993, Speocolpodes franiai Barr, 1973 and Speleodesmoides raveloi Mateu, 1978.

\section{Genus Galaicodytes gen. n.}

(Figs 2-4)

\section{Diagnosis}

Small body, anophthalmic, depigmented. Slender. Antennae long and filiform. Mandibles lacking seta in external sulcus. Maxillary and labial palps with terminal segment fusiform. Labial notch exhibiting prominent tooth. Head lacking conspicuous ocular convex shape, whith long, parallel genae and two supraocular setae. Pronotum subcordate, one anterior seta in lateral channel and one posterior seta very close to angle. Elytra narrow with subparallel sides; striae easily discernible; umbilicate series $(6+2+6)$ exhibing highly developed $3 \mathrm{rd}$, 9 th and 14th setae; discal setae present. Lacking wings. Legs moderately long; claws smooth. Male genitalia with uneven parameres lacking setae. Female genitalia with a 


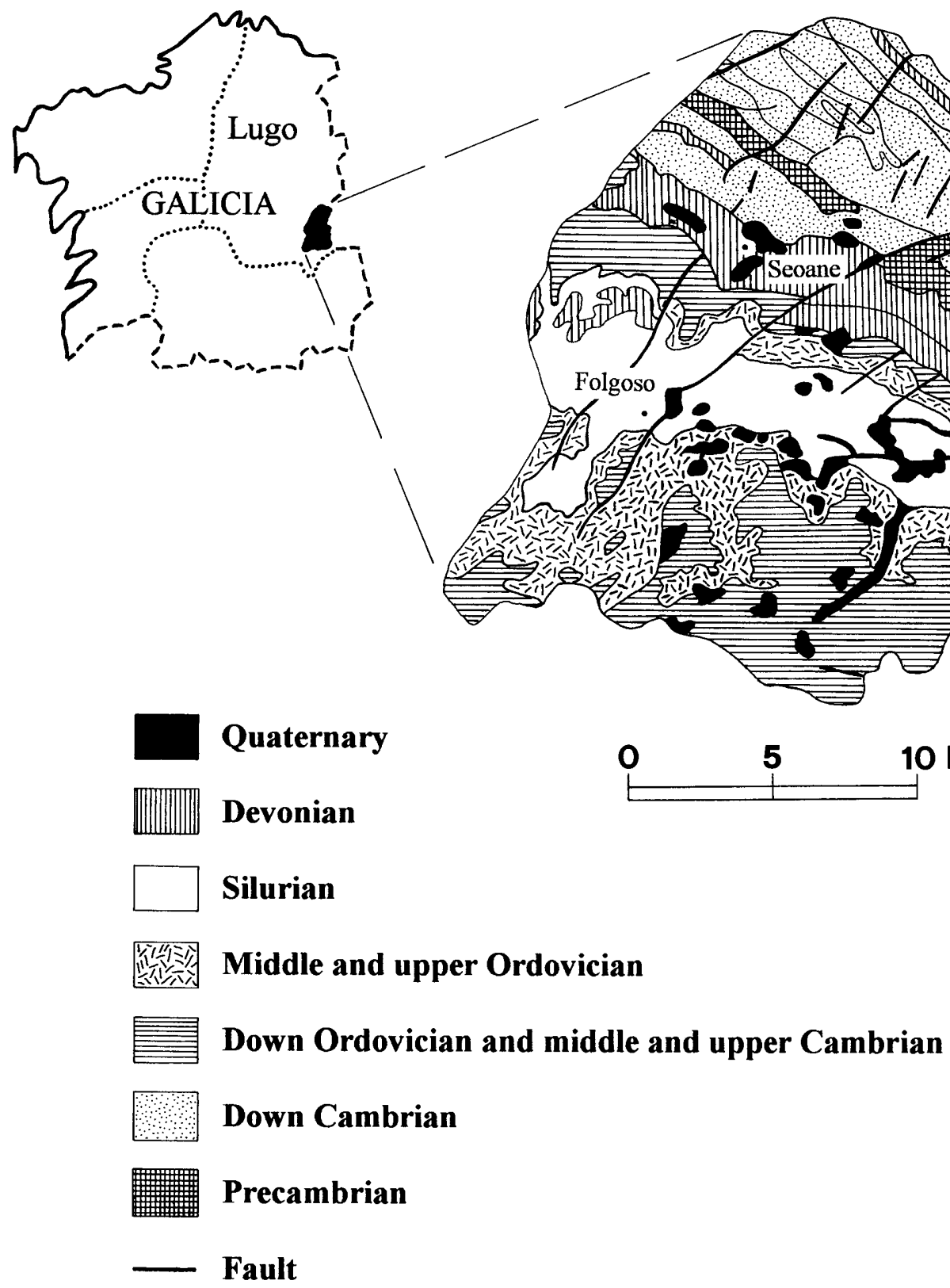

Fig. 1. Location and geological map of the Sierra de Caurel (according to Guitián, 1985).

line of spiniform setae on gonosubcoxite, highly developed spermatheca and spermathecal gland.

\section{Description}

Slender medium-sized hypogeous carabid (about $5 \mathrm{~mm}$ long); well-developed umbilicate setae; reddish-brown; depressed body, apparently glabrous.

Head lenticular. Eyes reduced to elliptical scars without ommatidia. Long genae with remnants of pubescence. Frontal furrows indistinct with short linear depression contacting the clypeofrontal groove. Mandibles acute. Labium notched with pointed tooth emerging from middle. Ligula bisetose. Maxillary and labial palps with terminal segment fusiform. Penultimate segment of labial palps with two long setae. Antennae filiform, 3rd to 11 th antennomere setose; 2nd antennomere with weakly discernible crown of setae in frontal half. Long seta and a few short setae on distal extreme of 1 st antennomere. Cephalic chaetotaxy: Two long supraocular setae, anterior seta near ocular scar; two clypeal setae, one on each side of anterior margin; six labral setae, outer ones larger; two setae near labial tooth, several setae (two very long) on labial base.

Pronotum subcordate with protruding anterior angles and obtuse blunt posterior angles; basal area curved towards posterior angles. Lateral channel wide and expanded in postangular region. Median longitudinal impression fine and superficial. Pronotal chaetotaxy: two marginal setae, one anterior on anterior $1 / 5$ of pronotum and one posterior next to posterior angle.

Prosternum with linguiform intercoxal apophysis. Intercoxal apophysis of mesosternum W-shaped, that of metasternum subtriangular. Large triangular scutellum. 


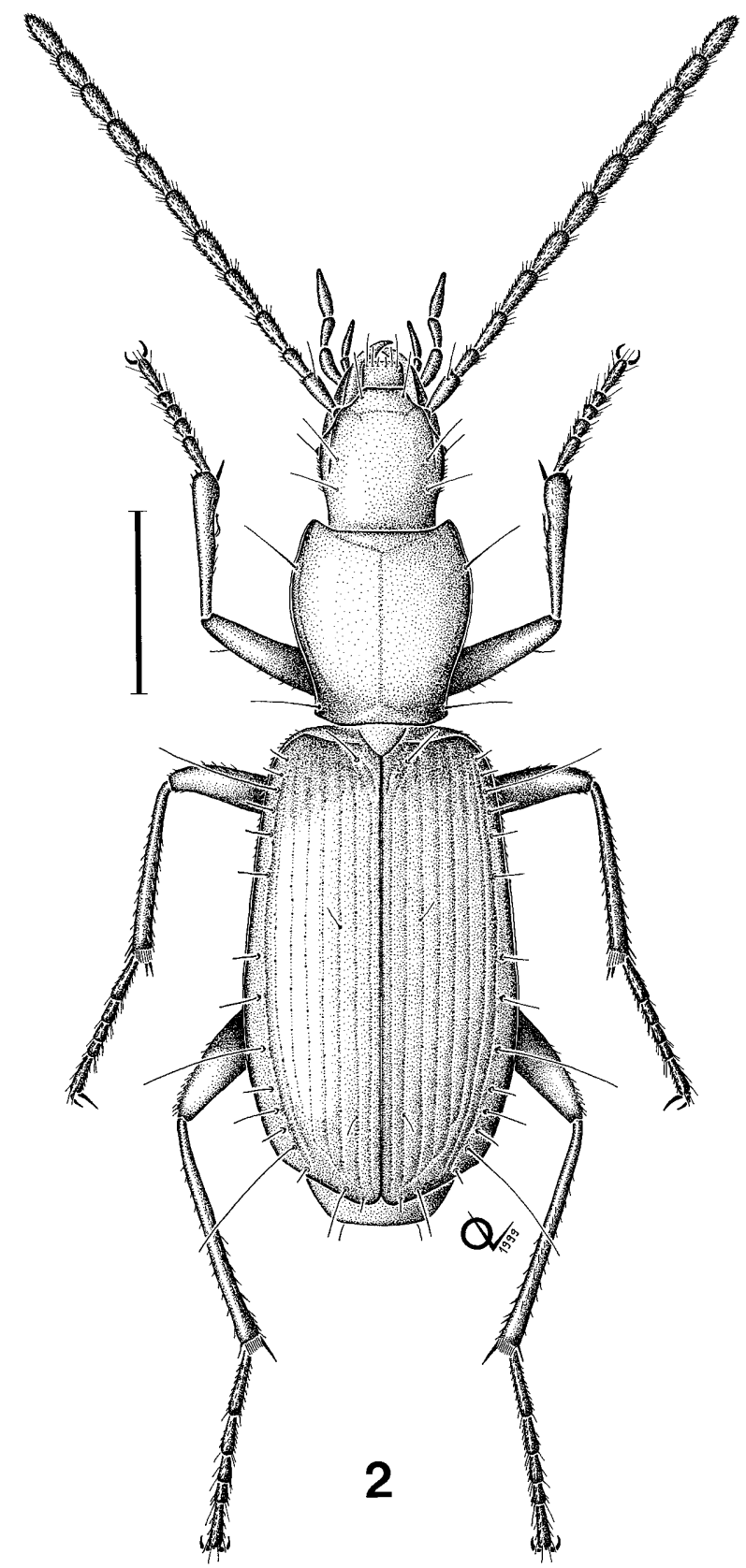

Fig. 2. Habitus of Galaicodytes caurelensis sp. n. Scale: 1 $\mathrm{mm}$

Elytra slightly convex, long and subparallel. Markedly protruding shoulders. Basal margin bordered from humeral curve to proximity of scutellum. Subhumeral region depressed. Oblique apical margin, leaving pygidium visible. Epipleura simple. Eight striae (easily discernible from 1 st to 7 th, 8 th next to umbilicate series), fine and regularly incised. Striae continuous along entire length of elytra, becoming obsolete from the base to the elytral tip. Clearly defined basal striole, located between the scutellum and 1st stria. Slightly convex interstriae of similar width except for 1 st which is slightly narrower. Elytral chaetotaxy: almost continuous umbilicate series; 6 humeral setae, 2 mid- and 6 subapical setae; one apical and one preapical seta; 2 discal setae on 3rd interstria, the anterior one next to the 3 rd stria and the posterior one very close to the 2 nd; scutellar pore on the confluence of 1 st and 2nd stria.

Legs long and gracile. Spherical prothoracic, conical mesothoracic and transverse metathoracic (aliform) coxae. Mesocoxae with 3 setae, metacoxae with 2, one of which is quite long. Uneven setae on femurs, in two lines of no more than 8 short setae on dorsal edge of pro-, meso- and metafemurs. Profemurs with $2-3$ ventral setae set out on posterior edge, mesofemurs with 2-4 setae and metafemurs with 2-3 setae, on anterior ventral face in both cases. Very slightly longitudinal grooves on protibiae. Protibial cleaner organ with internal notch (Ortuño, 1988) Mesotibial cleaner organ similar to comb model (Ortuño, 1988). Tarsi smooth, long and dorsally pubescent; length of first segment similar to the second and third combined. Fifth tarsomere ventrally setose, with smooth claws.

Etymology. Derived from "galaico" (Galician), which means originating from Galicia.

Galaicodytes caurelensis sp. $\mathbf{n}$.

(Figs 2-6)

Diagnosis

Apart from the characters described in the generic diagnosis, the following are also relevant: Antennae setulate from second antennomere. Labium bisetulate with simple conspicuous labial tooth. Head lenticular with short setation on genae. Basis of pronotum bevelled in area close to posterior angles. Elytra with pore and scutellar seta; two discal setae on 3 rd interstria, anterior one being close to 3 rd stria and posterior next to 2 nd stria. Dorsally setulate tarsi; male protarsi weakly dilated. Aedeagus with banana-shaped middle lobe and rounded, blunt tip. Spermatheca digitiform, spermathecal gland spherical.

\section{Description}

Length $4.5-4.7 \mathrm{~mm}$ (from tip of mandible to pygidium). Mandibles slightly asymmetrical, shear-like; acute terebra, retinaculum (dentiform in left mandible, long and depressed in right mandible), tricuspid tooth (homonymous cuspids in the left and heteronymous in the right) on the masticating edge. Microporous and microsetose maxillary palps; penultimate segment shorter than terminal. Labial palps with microporous and weakly microsetose last segment; penultimate segment with two long setae inserted in inner face as well as a few short setae. Pubescent antennomeres from 3rd (also at base of 2nd); from 2 nd -4 th proportionally narrower than the following (5th-11th); surface of the latter series covered with dense microporous formation, notably less so in basal series (2nd-4th). Prosternum with short scattered setation. Microserrulate lateral margin of elytra, more discernible in anterior half, continuing in the humeral region, above anterior margin of elytron, each small tooth crowned with a microseta. Micropubescent elytral integument (under magnification: $10 \times 25$ ). Humeral group of umbilicate series with third seta extraordinarily developed. The same occurs with 1 st and 5 th seta of subapical group. Male protarsus weakly dilated, showing no significant differences 

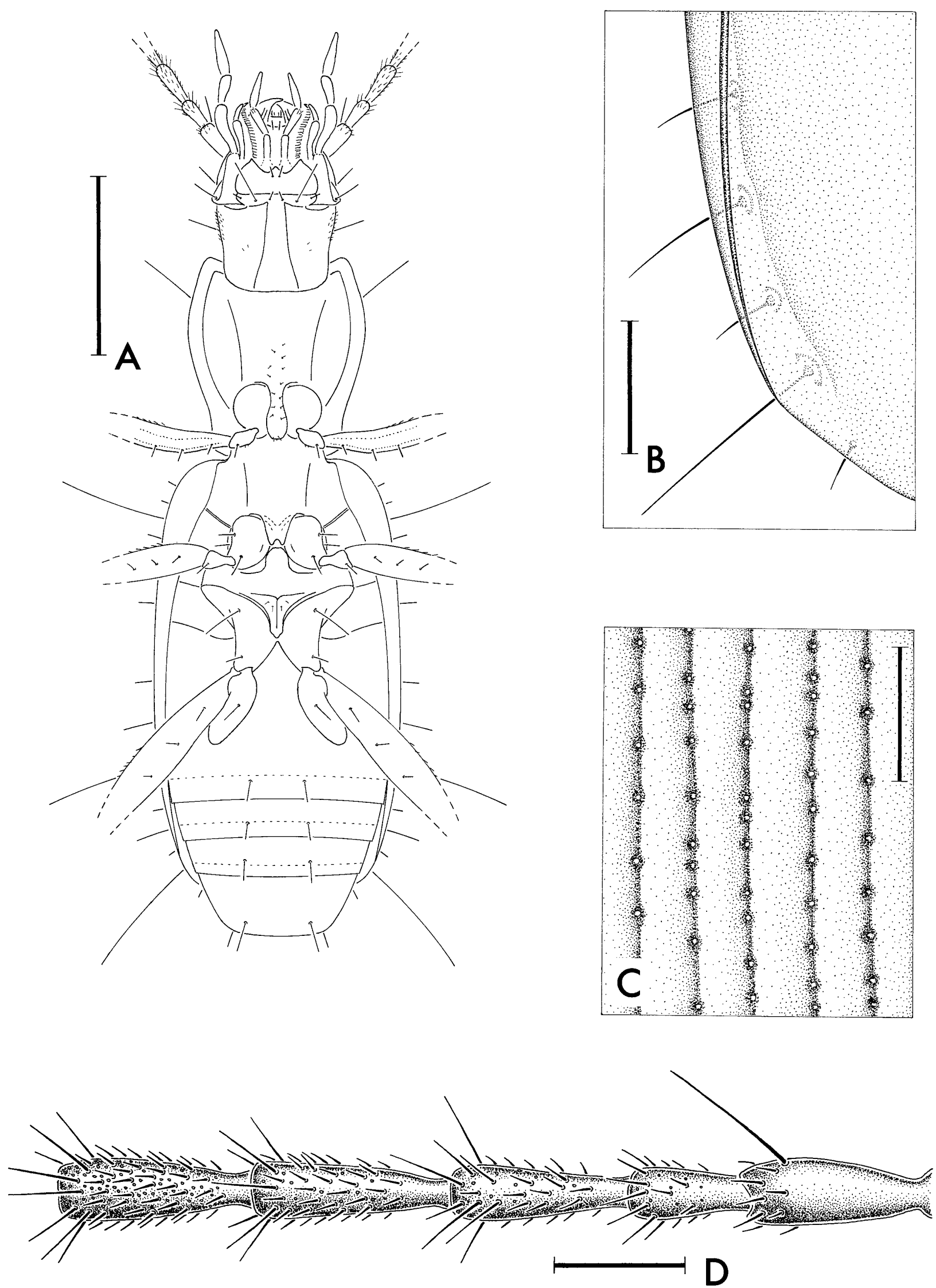

Fig. 3. Morphological details of Galaicodytes caurelensis sp. n. A - ventral characters; B - ventral view of elytral epipleura; C elytral striae and interstriae; D - first five antennomeres (I-V). Scale: A - $1 \mathrm{~mm}$; B, C, D - $0.2 \mathrm{~mm}$. 

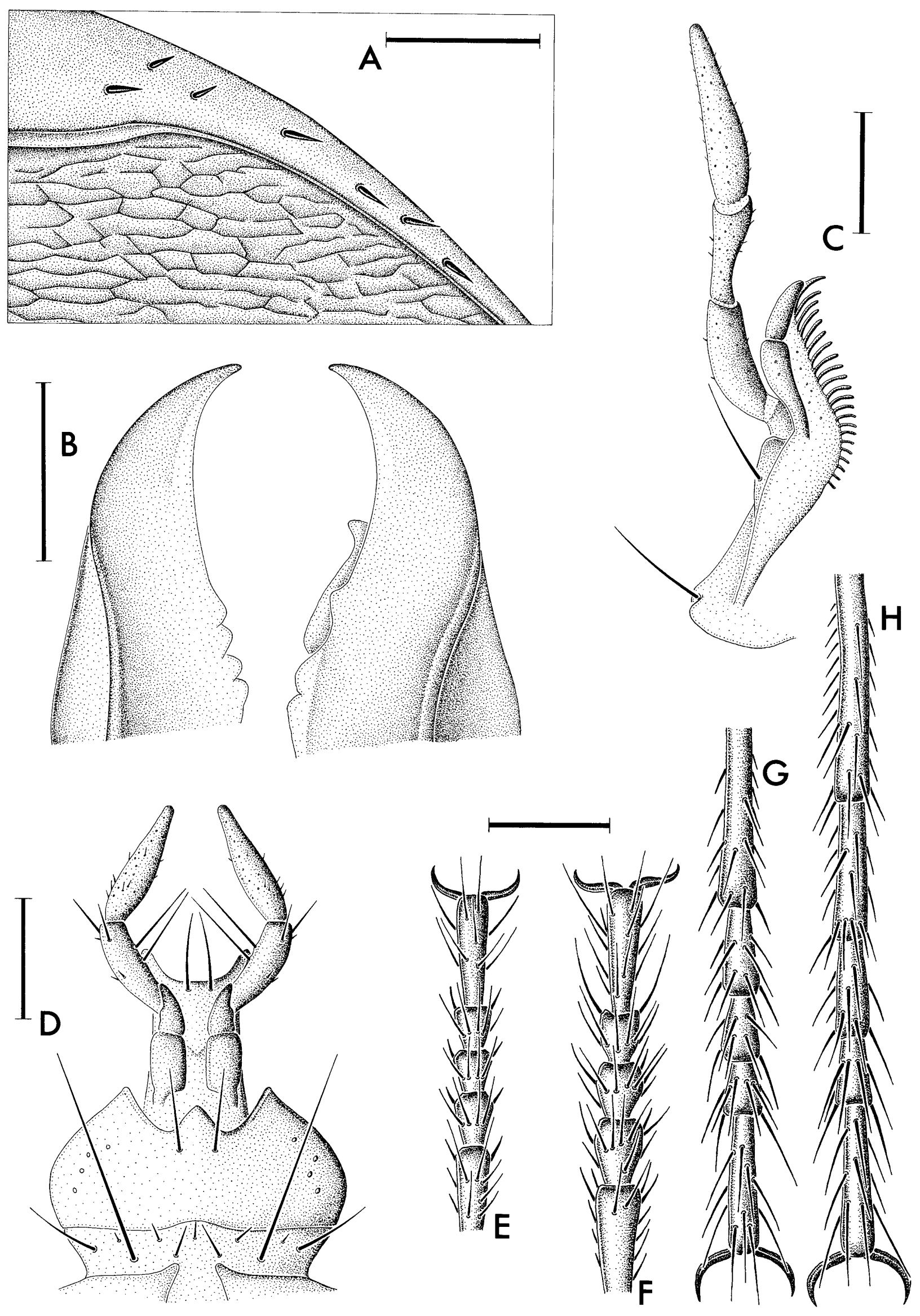

Fig. 4. Morphological details of Galaicodytes caurelensis sp. n. A - humeral region of right elytron; B - mandibles in dorsal view; $\mathrm{C}$ - maxilla and maxillary palp in dorsal view; D - labium, prebasilar ligula and labial palps in ventral view; E - female protarsus; $\mathrm{F}$ - male protarsus; $\mathrm{G}$ - male mesotarsus; $\mathrm{H}$ - male metatarsus. Scale: $\mathrm{A}-0.05 \mathrm{~mm}$; $\mathrm{B}-\mathrm{H}-0.2 \mathrm{~mm}$. 

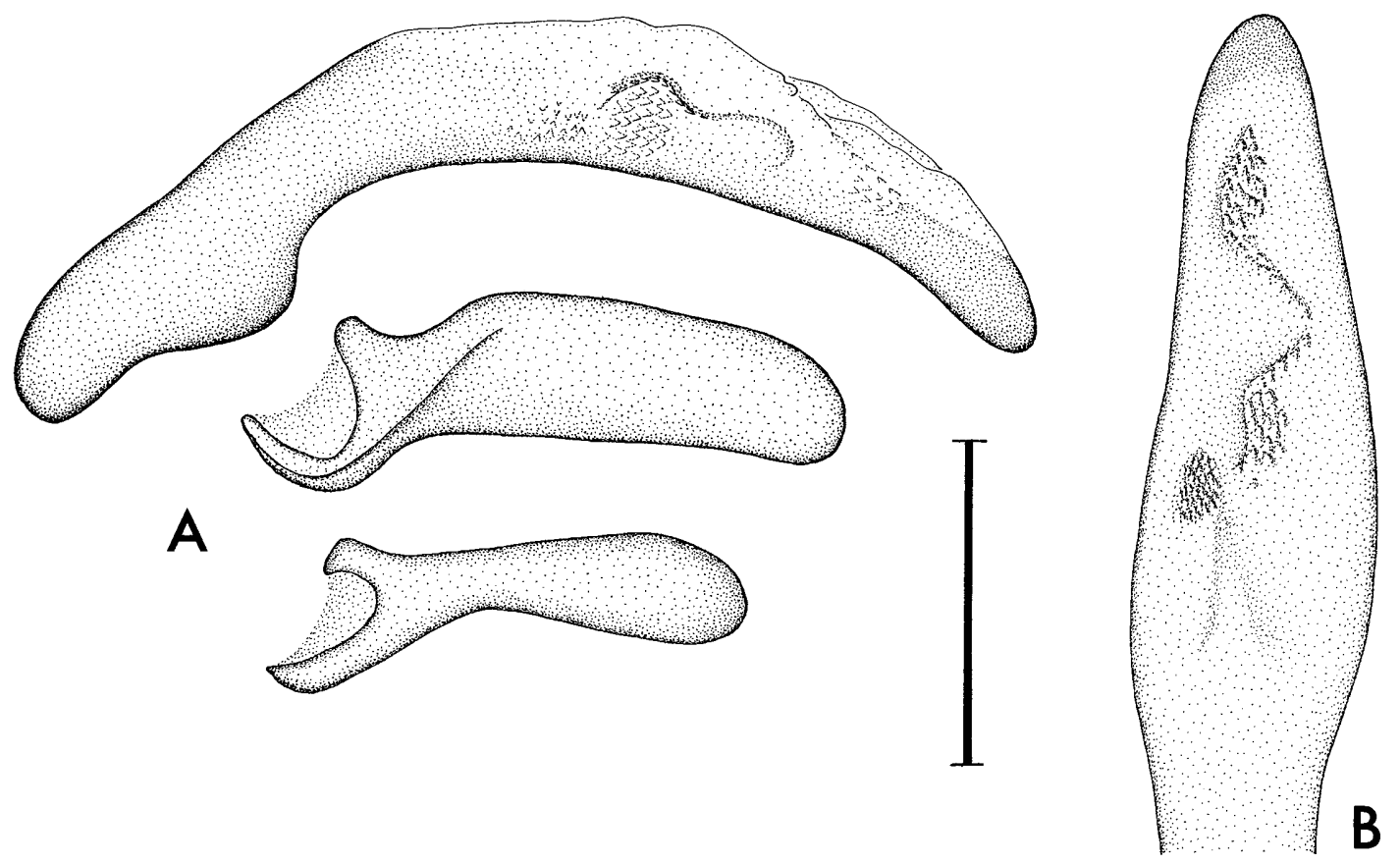

Fig. 5. Aedeagus of Galaicodytes caurelensis sp. n. A - median lobe and parameres in lateral view; B - median lobe in dorsal view. Scale: $0.2 \mathrm{~mm}$.

to female protarsus. Two guide setae on protibial cleaner organ.

Microsculpture in the shape of a polygonal net on the cephalic disc but transverse on the pronotum and elytra.

Male genitalia. In lateral view, median lobe widely arcuate ending in thick blunt point; in dorsal view, median lobe thick, with uneven sides converging in a more sclerotized area, the apical plate, which is slightly more asymmetrical. Inner sac with a series of scaly sclerotizations set out along a fold, or sinuous sulci. Spatuliform parameres without setae; the left one larger with almost parallel sides whilst the right one is smaller with pear-shaped anterior half.

Female reproductive tract. Genital shield formed by dimerous IX gonopods (IX gonocoxite and IX gonosubcoxite) and laterotergites IX. Gonocoxite unguiform with one or two thick ensiform setae on external edge; near internal edge and in subterminal position, two fine setae inserted in longitudinal fovea; there is another ensiform seta on the dorsal face, near the internal edge. Gonosubcoxite subtriangular, longer than wide; basal margin outlined by five acute ensiform setae. Aliform laterotergite with weakly sclerotized basal margin and ten short ensiform setae. Spermathecal complex completely membranous. Extraordinarily voluminous vagina opening distally into weakly discernible chalice-like bursa copulatrix with several folds in anterior part. Short spermathecal conduct opening out at one end of anterior part of bursa. Spermatheca digitiform, basal half with smaller diameter. Spermathecal gland spherical and joined to the complex by a duct of similar length to that of the spermatheca.

Sexual dimorphism. Both sexes show similar external morphology with slight differences in the dilation of the male protarsi. This characteristic is very weakly manifest in this species and is generally more noticeable in other species of the tribe Platynini. The last visible abdominal sternum is bisetose in the male and quadrisetose in the female.

Variability. A supernumerary seta was observed on the elytral disc of a male specimen; judging from its position next to the 3rd stria, we assume it is a duplication of the previous discal seta. A study of the genital shield of the only known female reveals a certain degree of asymmetry in the setation of the gonocoxite which again indicates the variability of these structures. This has been reported in other carabid groups: Pterostichini (Ortuño, 1991) and Trechini (Salgado \& Ortuño, 1998).

Type material. Holotype: 19 , Cueva do Eixe, $875 \mathrm{~m}$ [29TPH496222], Mercurín do Caurel (Lugo); 10.x.1998, J.M. Salgado leg. (Natural Science Museum, Madrid, Spain). Paratypes: 20 (immature), idem; 17.ix.1997, J.M. Salgado, leg. (one in coll. Ortuño, Dept. of Animal Biology, Alcalá University, Spain; one in coll. Salgado, Dept. of Animal Biology, León University, Spain).

Etymology. The species epithet means that it was collected in the Caurel region (Lugo, Spain).

\section{ECOLOGICAL FEATURES}

The Caurel region has the oldest materials of the Palaeozoic and a large variety of slate, shale, sandstones, quartzites, dolostones and limestones. The karstic outcrops of the lower Cambric and Ordovicican are well represented in this area: rocks of sedimentary origin which were subsequently deformed and metamorphosed (Guitián, 1985). The caves explored during the study are located in two formations, the "Calizas de Vegadeo" which are generally marmoreal limestones with a thickness of between 130 and $180 \mathrm{~m}$, and the "Calizas de la 


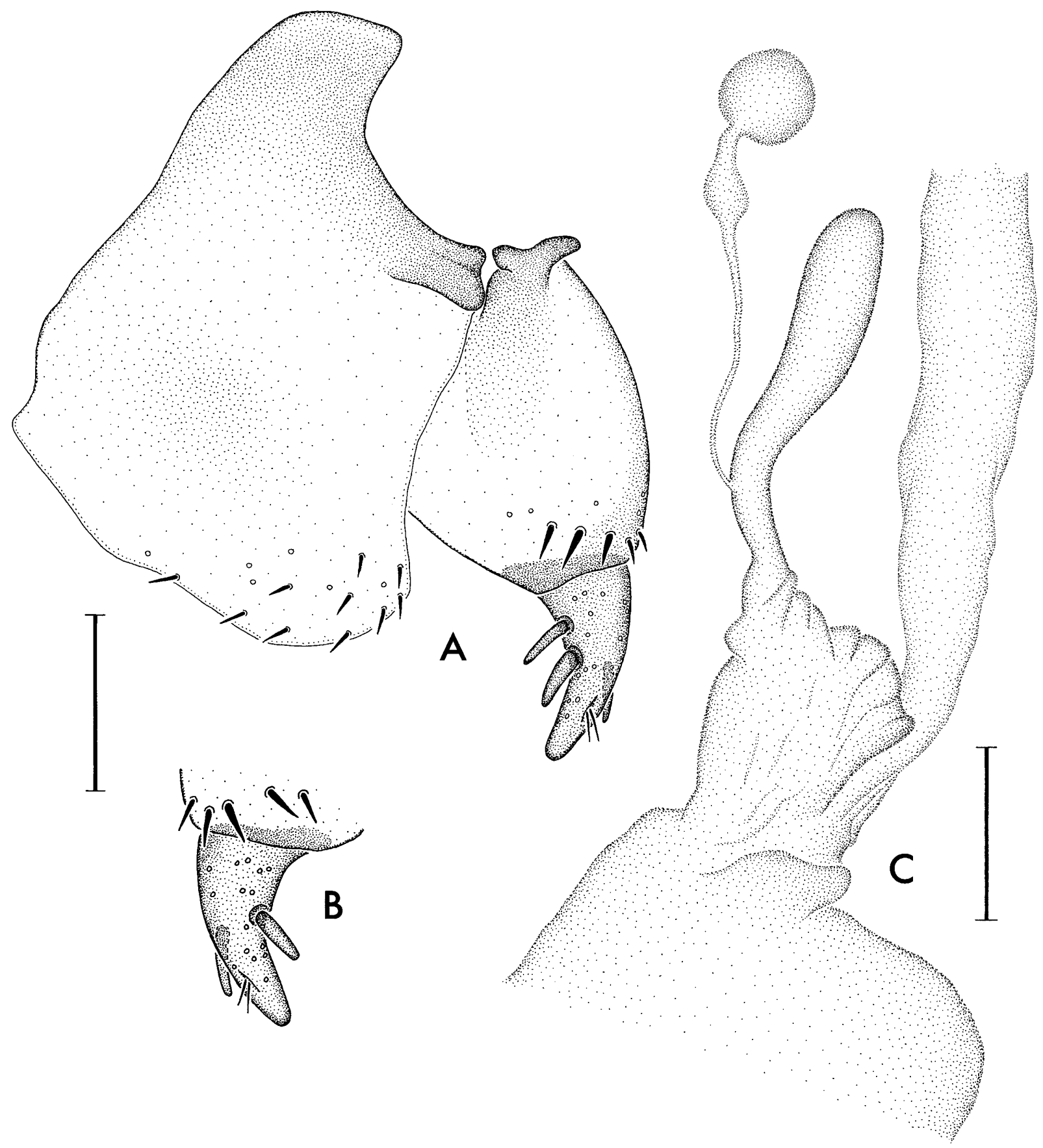

Fig. 6. Female genitalia of Galaicodytes caurelensis sp. $\mathrm{n}$. in ventral view. A - right genital shield; B - left gonocoxite and gonosubcoxite base; $\mathrm{C}$ - spermathecal complex. Scale: $0.1 \mathrm{~mm}$.

Aquiana" with a maximum thickness of $200 \mathrm{~m}$ (Rodríguez et al., 1993). It is common for both formations to be separated by layers of slate, shale and sandstones. These formations range from between 550 and $590 \mathrm{~m}$. The "Cueva do Eixe" (29TPH496222) is situated in the Sierra de Lóuzara at an altitude of $875 \mathrm{~m}$ with lower Cambric "Calizas de Vegadeo" outcrops. The immediate surroundings are also of importance as the fauna migrate through the fissures (mesocaverns sensu Howarth, 1983). Here, mechanical erosion occurs and the role of the wind, and in particular the continuous washing action of meteorical water which is more intense in a humid rainy climate $(1,900 \mathrm{~mm}$ average annual rainfall), is of great importance. Hence the craggy, rugged relief.

In the Caurel region there are limestone substrates surrounded by acidophilous areas. Oak trees (Quercus ilex ssp. ballota) are the predominant chorological element in the area where the cave is located. They are linked to the geological factor: outcrops of limestone in areas over 450 $\mathrm{m}$. Vegetation provides organic material which is filtered through the limestone, deposited in fissures and large spaces inside the cave and used as food by detritivores and some predators that have adapted to mixed feeding. 
From a speleological point of view the cave where Galaicodytes caurelensis sp. n. was captured forms part of a discontinuous underground system. The abyss and cavities are generally distant because the limestone areas are less than $200 \mathrm{~m}$ thick. The "Cueva do Eixe" is a gallery about $100 \mathrm{~m}$ long with a $35 \mathrm{~m}$ slope. It has abundant formations including stalactites, stalagmites and outflows. The ground is rocky and well-washed except for the entrance and a few lateral galleries where layers of clay have formed and organic material, in particular vegetal material, has accumulated, supporting epigeous entomological fauna. There are also large rocks in the main part of the cavity that have fallen as a result of dissolution and certain orogenic activity.

The atmosphere inside the cave scarcely alters throughout the year with relative humidity between $96-98 \%$, which is a main factor for the existence of cavedwelling fauna. Changes in temperature are more noticeable, ranging from $7^{\circ} \mathrm{C}$ in winter to $12^{\circ} \mathrm{C}$ in summer.

Arthropods belonging to various groups have been captured in the cave and are being studied at present. Crustacea: Isopoda; Arachnida: Pseudoscorpionida, Opilionida, Araneida and Acari; Diplopoda: Julida, Polydesmida and Glomerida; Chilopoda: Lithobiomorpha and Geophilomorpha; Insecta: Plecoptera, Lepidoptera, Hymenoptera and Coleoptera. The most important Coleoptera are the very common Laemostenus (Anthisphodrus) peleus (Schaufuss, 1861) and some specimens of Trechus fulvus Dejean, 1831 (Carabidae), both eurytopic species found in Basque, Cantabrian, Gallician and Iberian caves. Two troglobitic Coleoptera, Leonesiella bergidi (Cholevidae) and Domene (Lathromene) bergidi (Staphylinidae), also occur in the cave.

\section{TAXONOMIC POSITION AND DISCUSSION}

Over the last 45 years numerous cave-dwelling species of Platynini have been discorved. In some cases they belong to monotypical genera corresponding to relict species whose ancestry is extinct. These interesting discoveries have been made in places as far away as Japan (Habu, 1950; Uéno, 1952, 1955), Taiwan (Uéno \& Saito, 1991); Papua-New Guinea (Moore, 1977; Casale, 1982); Hawaii (Liebherr \& Samuelson, 1992; Liebherr \& Zimmerman, 1998); Mexico and southern United States (Barr, 1960; Bolívar, 1944; Bolívar \& Hendrichs, 1964), Guatemala (Barr, 1973) and Venezuela (Mateu, 1978; Monguzzi \& Trezzi, 1993).

A considerable number of papers have been published based on this interesting entomological material in which the authors have endeavoured to establish phylogenetic links amongst different genera. However, it remains impossible to classify adequately the cave-dwelling Platynini, though they undoubtedly seem to be derived from epigeous lineages.

Neotropical Platynini troglobites Speleocolpodes Barr, 1973 and Speleodesmoides Mateu, 1978, were thought to be related to the genus Colpodes (Barr, 1973; Mateu, 1980), which has been well-defined by Liebherr (1998) and is restricted to Indonesia. Tepuydites Monguzzi \&
Trezzi, 1993 and Dyscolus Dejean, 1831, form a welldefined "colpodian" type group because of their asymmetrical bilobate fourth tarsomere (particularly in the metatarsus), although Tepuydites presents more specialized characters for hypogeous life. The genus Rhadine LeConte, 1948 is an adelphotaxon of Tanystoma Motschulsky, 1845 (see Liebherr, 1985); Rhadine appears to be specialized Tanystoma, distinguished by elongate appendages, constriction of the neck, narrowing of the prothoracic base, and prolongation of latero-basal pronotal lobes (Liebherr, 1986), hence its "aphaenopsian" facies (Barr, 1982). Mexiphodrus Barr, 1965, exhibiting less specialized cavernicolous forms with a "sphodroid" facies, and in some cases "aphaenopsian" facies, is related to the Platynus phyletic line (sensu Whitehead, 1973).

The cave-dwelling Platynini of New Guinea form a non-natural polyphyletic group (Casale, 1982) and the species present a highly specialised "hypogeous" morphology; Speagonum Moore, 1977, and Trogloagonum Casale, 1982 are examples. However, Gastragonum Darlington, 1952 (G. caecum Moore, 1977) presents structures that are not very specialized in relation to cavedwelling life since most of its specimens are mesophilous habitants of mountainous regions.

The two Hawaiian troglobites are independently derived from parapatric epigean ancestors, as shown by the different levels of evolution and adaptation to the underground environment (Liebherr \& Samuelson, 1992; Liebherr \& Zimmerman, 1998); there is also the possibility of an adaptive radiation, as indicated by Casale (1988) for the eucavernicolous species belonging to the tribe Sphodrini, the sister of the tribe Platynini (Liebherr, 1986).

Species belonging to the genera Jujiroa Uéno, 1952 and $J a$ Uéno, 1955 constitute a well-defined group in Japan and Taiwan. The troglobitic specimens that have adapted relatively well to the hypogeous environment have a "sphodroid" type morphology.

At present it is not possible to discuss affinities of Galaicodytes. In the following part we consider some characters which may prove helpful in establishing relationships.

\section{Relation with taxons belonging to euromediterranean fauna}

Galaicodytes caurelensis sp. n. presents a series of morphological characteristics which, when considered as a whole, indicate that it should be placed in the subfamily Pterostichinae close to the Platynini, Synuchini and Sphodrini. Male and female genitalia support a close relationship with the tribe Platynini. Lindroth (1956) and Jeanne (1988) pointed out the most significant differences of the three tribes which apparently form a very homogeneous group of carabids. These differences are found in the paramere morphology of the male genitalia and in the female genital shield. The Platynini (also in Galaicodytes caurelensis sp. n.) present an aedeagus with both parameres conchoid (Fig. 5A) (the left is larger than the right), whilst the Sphodrini or Synuchini have a virguleor handle-shaped right paramere respectively. A study of 
the female genital shield clearly and definitely places $G$. caurelensis $\mathrm{sp} . \mathrm{n}$. amongst the Platynini. The gonosubcoxite of this species is edged with a series of spiniform setae in the basal region (Figs 6A-B), which also appear on the genital shield of the Platynini whereas this area is glabrous in the Sphodrini and Synuchini (Habu, 1978; Casale, 1988; Jeanne, 1988).

Hypogeous adaptations in $G$. caurelensis sp. n. make the task of placing it in Platynini systematics difficult. If we compare it to the Euromediterranean genera, we find three taxa which do show greater similarity to the new genus: Cardiomera Bassi, 1834; Anchomenus dorsalis (Pontoppidan, 1763), and Europhilus Chaudoir, 1859 (subgenus of Agonum Bonelli, 1819). All of them have a dentate labium and a pubescent 3rd antennomere. The latter characteristic should be interpreted as derived, since glabrous 3rd antennomere is widespread in Platynini and is shared by its sister Sphodrini (Liebherr, pers. comm.). However, G. caurelensis sp. n. has a tarsus with pubescent dorsum, a significant difference from the abovementioned genera (Figs 4E-H).

Cardiomera genei Bassi, 1834 has a ventrally glabrous onychium, meso- and metatarsus with furrows, bilobate fourth tarsomere, truncate last segment of the palps, lacks posterior pronotal seta and the dorsal microsculpture of the integument is polygonal. All of these characters differ from $G$. caurelensis sp. n.; although the shape of the spermathecal complex is somewhat similar, there are significant differences in the gonosubcoxite setation (Ortuño, 1995).

Europhilus and $G$. caurelensis sp. n. show the following differences: Europhilus species have a trapezoid or suborbicular pronotum, denser setation of the elytral disc, meso- and metatarsus with furrows and polygonal dorsal microsculpture of the integument (on head, pronotum and elytra). Europhilus female genitalia are very different from $G$. caurelensis sp. n. especially in relation to the spermatheca (Ortuño et al., 1999). Anchomenus dorsalis (Pontoppidan, 1763) has the most similar external morphology, with the following differences: Lack of adaptation to underground life (blindness, depigmentation and hypertrophy of some setae), dorsally glabrous tarsi, more discal setae on the elytron, lack of posterior pronotal seta, meso- and metatarsus with furrows, and very dense almost tegular polygonal microsculpture; also, the tip of the spermatheca in the genus Anchomenus is filamentous (Liebherr, 1991; Ortuño, 1995). Finally, of the Euromediterranean carabid fauna, Oxypselaphus obscurus (Herbst, 1784), which has a glabrous 3rd antennomere, also shows notable similarities to $G$. caurelensis sp. n., such as small dimensions, the tarsus lacking furrows but with setae, male protarsus very weakly dilated, umbilicate series with 14 pores $(6+2+$ 6 ), and a different type of microsculpture depending on the part of the body: in the form of polygonal net and transversal (pronotum and elytra); it also differs from $G$. caurelensis in the female genitalia and particularly the subapical constriction of the spermatheca (Ortuño, 1995).

\section{KEY TO THE PLATYNINI GENERA OF THE EUROMEDITERRANEAN REGION}

1 Labial notch lacking middle tooth. 1st antennomere similar in width to 2nd. Orbicular pronotum with acutely rounded sides and posterior angles. Integument partially or totally reddish-brown or brown, in some cases with golden streaks. Appendages generally reddish-brown $\ldots \ldots \ldots \ldots \ldots \ldots$

Olisthopus Dejean, 1828

- Labial notch with middle tooth (Fig. 4D) . . . . . . . 2

2 Antenna clearly pubescent from $3 \mathrm{rd}$ antennomere (Fig. 3D)

Antenna pubescent from 4 th antennomere .......... 6

3 Vestigial eyes, reduced to a small ocular scar. Depigmented integument. Subcordate pronotum with angular seta. Tarsi with pubescent dorsal surface (Figs $4 \mathrm{E}-\mathrm{H}$ ). Habitus as in Fig 2 and $3 \mathrm{~A} \ldots \ldots \ldots \ldots \ldots$ Galaicodytes gen. $\mathrm{n}$.

- Perfectly developed eyes. Glabrous dorsal surface of tarsomeres

4 Tarsi with 4th segment bilobate. Onychium with glabrous ventral surface. Very long, prominent mandibles. Genae longer than eye. Subcordate pronotum with acutely pointed posterior angles. Monospecific genus with Tyrrhenian type circummediterranean distribution

Cardiomera Bassi, 1834

- 4th segment of tarsus not bilobate. Ventrally setose onychium. Mandibles of normal length. Genae shorter than eye. Pronotum subcordate or not, hind angles obtuse or rounded

Subcordate pronotum lacking angular seta. Gi......... and pronotum. Bicoloured elytra. Spermatheca with filamentous tip ......... Anchomemus Bonelli, 1810 (part)

- Pronotal margins progressively arched but not sinuate; angular seta present. Black or red-brown pronotum and head. Elytra generally unicolorous. Spermatheca with more or less dilated tip. Subgenus of Agonum Bonelli, $1810 \ldots$... Europhilus Chaudoir, 1859

6 Aedeagus with setulose parameres .. Sericoda Kirby, 1837

- Aedeagus with parameres lacking setae .......... 7

7 Apterous species with short metaepisterna and weakly prominent humeral region. Small digitiform spermatheca inserted in base of oviduct (see Liebherr, 1989b)

Batenus Motschulsky, 1864

- Winged species with long metaepisterna and humeral region more protruding and rounded. Different spermathecal complex

8 Pronotum with visibly sinuate lateral margins and welldefined posterior angles, subrectangular or slightly diverging $\ldots \ldots \ldots \ldots \ldots \ldots \ldots \ldots \ldots \ldots$ Progressively arched margins on pronotum and posterior angles rounded or weakly discernible $\ldots \ldots \ldots \ldots .12$

9 3rd antennomere considerably longer than fourth. Size larger $(9-13 \mathrm{~mm}) \quad \ldots \ldots \ldots \ldots \ldots \ldots \ldots \ldots \ldots \ldots . \ldots \ldots$

- 3rd antennomere similar in length to fourth. Size smaller (5-8 $\mathrm{mm})$

10 Pronotum small, subquadrate, lacking angular seta. Metallic blue integument. Spermatheca with filamentous tip ..... Anchomenus Bonelli, 1810 (part)

- Pronotum large, subcordate, with angular seta. Black integument. Spermatheca more or less long, tip never filamentous

Platynus Bonelli, 1810

11 Transverse pronotum, longer than wide. Elytra with smooth striae and flat interstriae. Tarsi dorsally glabrous. Meso- and metatarsi with furrows on dorsum. Size large $(7-9 \mathrm{~mm})$. (Monospecific genus widely distributed in Palaearctic region) .................. Paranchus Lindroth, 1974 
- Slender pronotum, almost as long as wide. Elytra with pointed striae and convex interstriae. Tarsi with hairs on dorsum. Dorsally smooth meso and metatarsi. Size small (5-6.5 mm). (Monospecific genus widely distributed in Palaeartic region) ....... Oxypselaphus Chaudoir, 1843

12 Posterior seta of pronotum situated well in front of angle. Elytron lacking discal setae. Endemic monospecific genus from Sardinia (see Vigna Taglianti \& Franzini, 1976) Agelaea Gené, 1839

- Posterior seta of pronotum near angle. Discal setae of elytron present. Melanic integument or bright metallic tone Agonum Bonelli, 1810

\section{Relation with hypogeous taxa}

The other hypogeous or cave-dwelling Platynini present significant differences to Galaicodytes gen. n., although many of their characters are similar due to a marked homoplasy: this is the case of Trogloagonum novaehiberniae, Speleodesmoides raveloi and some species of the genus Jujiroa. However, some of the more important characters that differentiate these Platynini from Galaicodytes gen. $\mathrm{n}$. will be pointed out later.

The Asiatic forms (Taiwan and Japan) such as Ja Uéno, 1955 (monospecific) and Jujiroa Uéno, 1952 include a series of species belonging to a phyletic line of "sphodroid" facies easily distinguishable from the others because they all have a bifidous labial tooth; in the case of Jujiroa, the apex of the elytral suture is dentate. Both genera lack the tomentum on the third antennomere and have a markedly bilobate fourth tarsomere. The subterranean adaptation of these species is not very marked since the hypogeous or cave-dwelling forms are perfectly oculate and microphthalmic (Uéno, 1952, 1955, 1993; Uéno \& Saito, 1991).

The other hypogeous or cavernicolous species of Platynini possess a more or less acuminate and simple labial tooth. The three species from Papua-New Guinea (Speagonum mirabile, Gastragonum caecum and Trogloagnonum novaehiberniae) leave no doubt as to their perfect adaptation to underground life: integument depigmented, eyes reduced to scars lacking ommatidia, and noticeable lengthening of the appendages, particularly the antennae; however the 3rd antennomere and dorsum of the tarsi is glabrous in the three species (Moore, 1977; Casale, 1982). Both characteristics are sufficent to place G. caurelensis sp. n. further apart from these three representatives of the Southern hemisphere. We would like to point out that Speagonum mirabile has almost "aphaenopsian" facies with a much greater lengthening of the antennae than $G$. caurelensis sp. n. and also that Gastragonum caecum has developed a very different body structure to the Iberian species, the great length of the antennae and the orbicular shape of the pronotum are the two most outstanding characters. Trogloagonum novaehiberniae, on the other hand, is similar to G. caurelensis $\mathrm{sp}$. $\mathrm{n}$. in its shorter antennae and the general shape of the body (head, pronotum and elytra). Nevertheless, the female genital shield is different in relation to the first two species, whilst $T$. novaehiberniae presents a significant reduction in the thorn-like setation of the gonosubcoxite and the lack of the thick setae of the gonocoxite
(Casale, 1982), compared to G. caurelensis sp. n. which has more setae on both structures (Figs 6A-B). The Hawaiian species belonging to the genus Atelothrus and considered troglobites have certain characteristics in common with $G$. caurelensis sp. n., such as the setation on the 3rd antennomere and, in A. aaae, the dorsally pubescent tarsomeres. The female genitalia are somewhat similar to $G$. caurelensis, but the bursa copulatrix of the Hawaiian species is partially lined with microtrichia or crested scales, and the sensory fovea of the gonocoxite is very close to the tip (Liebherr \& Samuelson, 1992).

In the southern Nearctic region the cave-dwelling representatives of the Platynini are Rhadine LeConte, 1848 (=Spelaeorhadine Bolívar, 1944) and Mexisphodrus Barr, 1965. The first lineage includes several subterranean species (Bolívar, 1944; Barr, 1960; Bolívar \& Hendrichs, 1964) with "aphaenopsian" facies showing varying adaptation to underground life as it has perfectly oculate species ( $R$. araizai Bolívar, 1944; R. howdeni Barr \& Lawrence, 1960; amongst others), microphthalmic or practically anophthalmic species ( $R$. persephone Barr, 1960; R. subterranea Barr, 1960; and others). These forms coincide with Galaicodytes gen. n. in the simple labial tooth, the labial palp with few short microscopic setae and the male protarsus weakly dilated. Both genera show significant differences with regard to the pilosity of the antennae and legs. In Rhadine the tarsi and 3rd antennomere are dorsally glabrous. Mexisphodrus, as in the case of the previously mentioned species, has similar labial characters to Galaicodytes gen. n. However, it differs in the lack of setation on the dorsum of the tarsi and the third antennomere, as well as in the noticeably bilobate fourth tarsomere. The female genitalia of Rhadine, in some of the epigeous species (Liebherr, 1986; Dajoz, 1998), are somewhat similar to $G$. caurelensis sp. n., although the gonocoxite is slightly different in shape and setation, depending on the species (this observation was made from diagrams provided by J.K. Liebherr). In general, the shape of the female genitalia places Galaicodytes gen. n. closer to genus Rhadine.

Although it has no cave-dwelling representatives, the Nearctic genus Tanystoma, adelphotaxon of Rhadine, is worthy of comment because of its female genitalia being extraordinarily similar to Galaicodytes gen. n. (see Liebherr, 1985, 1989a).

Finally, Central and South America contribute three hypogeous or cave-dwelling species (Barr, 1973; Mateu, 1978; Monguzzi \& Trezzi, 1993). Unlike G. caurelensis $\mathrm{sp} . \mathbf{n}$. these species present a strongly bilobate fourth tarsomeres (at least the pro- and mesothoracic ones). Also, in the case of Speocolpodes franiai and Tepuydites anyanensis, the third antennomere is completely glabrous, whilst in Speleodesmoides raveloi it is pilose in apical half. $T$. auyanensis is the least specialized of these three species. The genital shield and the spermathecal complex of $T$. auyanensis is somewhat similar to that of the new Iberian species. 


\section{BIOGEOGRAPHICAL COMMENTS}

Both the spatial distribution and evolution of the species are strongly influenced by geological history, in particular by environmental factors which could become barriers. Palaeogeography and the climate are of particular relevance in the evolution and formation of troglobitic communities. Thus, we can pose the question of whether the cave-dwelling Platynini are the ecological and geographical vicariants of the Palaearctic Sphodrini (Casale, 1982) (the Japanese troglobitic species is an example), or what factors have led to the colonization of caves by Platynini in tropical forest environments (Mateu, 1980) when there were no glacial periods during the Pleistocene in these areas. For species adapted strictly to high humidity levels, endemic centres would undoubtedly be refuges in vegetation in tropical areas during the dry stages of glacial periods (Trajano, 1995); in the warm areas of Europe underground colonization was influenced by significant changes in temperature during glacial or interglacial periods, and it is possible that in lavas the Platynini species simply colonize small voids in the ground, and move into the caves if suitable resources exist to support these populations (Liebherr \& Samuelson, 1992). Galaicodytes caurelensis sp. $\mathrm{n}$. is a relict species found in an area of great selective pressure caused by climatic changes at the end of the Tertiary and Pleistocene, in need of a refuge to survive.

As for the relationship between $G$. caurelensis and other Platynini underground colonizers, we can conjecture that, after examining the morphological characters, in particular the female genitalia, greater affinity with species belonging to the Nearctic group Rhadine-Tanystoma than with species from the northern Neotropical region Speocolpodes-Speleodesmoides-Tapuydites or with species found in Pacific Isles. This once again confirms that they are species derived from a common ancestor that was extended through the Late Cretaceous from eastern North America to Europe (Noonan, 1988) and this is the sister area relationship defined by vicariance of the Atlantic Ocean dated Late Eocene (Jeannel, 1942).

ACKNOWLEDGEMENTS. We wish to express our thanks to S.-I. Uéno, A. Casale, T. Deuve, P. Moret and N. Ito for their advice and for providing bibliographical material; and especially to J.K. Liebherr whose invaluable comments contributed greatly to improving the paper. Supported by the Fauna Ibérica, SEUIDGES PB95-0235.

\section{REFERENCES}

BARR T.C. 1960: The cavernicolous beetles of the subgenus Rhadine, genus Agonum (Coleoptera: Carabidae). Am. Midl. Nat. 64: 45-65.

BARR T.C. 1973: Speocolpodes, a new genus of troglobitic beethes from Guatemala (Coleoptera: Carabidae). Psyche 80: 271-276.

BARR T.C. 1982: The cavernicolous anchomenine beetles of Mexico (Coleoptera: Carabidae: Agonini). Texas Mem. Mus. Bull. 28: 161-192.

Blanco E. 1996: El Caurel, las plantas y sus habitantes. Fundación Caixa Galicia, Santiago de Compostela, 203 pp.
Bolívar C. 1944: Descubrimiento de un Rhadine afenopsiano en el estado de Nuevo León, México. Ciencia 5: 25-28.

Bolívar C. \& Hendrichs J. 1964: Agoninos cavernícolas nuevos del género Rhadine de Nuevo León, Coahuila y San Luis Potosí (México). Ciencia 23: 5-16.

Casale A. 1982: Nuovi Carabidi del Marocco, di Grecia e di Papua-Nuova Guinea (Coleoptera). Rev. Suisse Zool. 89: 229-244.

CASAle A. 1988: Revisione degli Sphodrina (Coleoptera, Carabidae, Sphodrini). Monografie 5. Museo Regionale di Scienze Naturali, Torino, $1024 \mathrm{pp}$.

Casale A., Vigna Taglianti A. \& Juberthie C. 1998: Coleoptera Carabidae. In Juberthie C. \& Decu V. (eds): Encyclopaedia Biospéologica. Vol. 2. Sociéte de Biospéologie, Moulis-Bucarest, pp. 1047-1081.

Dajoz R. 1998: Deux Coléoptères terricoles nouveaux de Californie: Araeoschizus muthi (Tenebrionidae) et Rhadine albamontana (Carabidae). Nouv. Rev. Entomol. (N.S.) 15: 87-94.

Gưtrán F. 1985: Estudio del medio natural de las montañas gallegas. I. O Caurel. Universidad de Santiago de Compostela, Santiago de Compostela, $102 \mathrm{pp}$.

HaBU A. 1950: On some cave-dwelling Carabidae from Japan (Coleoptera). Mushi (Fukuoka) 21: 49-53.

HABU A. 1978: Fauna Japonica. Carabidae: Platynini (Insecta: Coleoptera). Keigaky, Tokio, 447 pp.

Howarth F. 1983: Ecology of cave arthropods. Annu. Rev. Entomol. 28: $365-389$

JEANNE C. 1988: Carabiques nouveaux ou remarquables $\left(8^{\mathrm{e}}\right.$ note). Bull. Soc. Linn. Bordeaux 26: 5-27.

JEANNEL R. 1942: La Genèse des Faunes terrestres. Eléments de Biogéographie. Presses Univers. de France, Paris, 513 pp.

LieBHERR J.K. 1985: Revision of the Platynine carabid genus Tanystoma Motschulsky (Coleoptera). J. N. Y. Entomol. Soc. 93: $1182-1211$.

LieBHERR J.K. 1986: Cladistic analysis of North American Platynini and revision of the Agonum extensicolle species group (Coleoptera: Carabidae). Univ. Calif. Publ. Entomol. No. 106, $198 \mathrm{pp}$.

LIEBHERR J.K. 1989a: Tanystoma diabolica new species (Coleoptera: Carabidae: Platynini) from Baja California and its biogeographic significance. J. N. Y. Entomol. Soc. 97: 173-186.

LieBHERR J.K. 1989b: Redescription of Platynus prognathus Van Dyke (Coleroptera: Carabidae: Platynini) and circumscription of Lindroth's decentis and hypolithos groups. J. N. Y. Entomol. Soc. 97: 430-437.

LIEBHERR J.K. 1991: Phylogeny and revision of the Anchomenus clade: the genera Tetraleucus, Anchomenus, Sericoda, and Elliptoleus (Coleoptera: Carabidae: Platynini). Bull. Am. Mus. Nat. Hist. 202: 1-163.

LieBHERR J.K. 1998: On Rembus (Colpodes) brunneus MacLeay (Coleoptera: Carabidae, Platynini): redescription and relationships. J. Nat. Hist. 32: 987-1000.

LiebHerr J.K. \& SAMUELSON A. 1992: The first endemic troglobitic carabid beetles in Hawaiian lava tubes (Coleoptera: Carabidae). Pan-Pac. Entomol. 68: 157-168.

LiebHerr J.K. \& ZmMmerman E. 1998: Cladistic analysis, phylogeny and biogeography of the Hawaiian Platynini (Coleoptera: Carabidae). Syst. Entomol. 23: 137-172.

LindRoth C. 1956: A revision of the genus Synuchus Gyllenhal (Coleoptera: Carabidae) in the widest sense, with notes on Pristosia Motschulsky (Eucalathus Bates) and Calathus Bonelli. Trans. R. Entomol. Soc. Lond. 108: 485-576.

Mateu J. 1978: Speleodesmoides raveloi, nuevo género y especie de carábido troglobio en una cueva de Venezuela (Coleoptera: Carabidae). Bol. Soc. Venez. Espeleol. 9: 21-28. 
Mateu J. 1980: Commentaires sur deux Agonini troglobies de l'Amerique Centrale et Meridionale. Mém. Biospéol. 7: 209-213.

Monguzzi R. \& TREzzi G. 1993: Tepuydites auyanensis, nuovo genere e nuova specie di Platinino ipogeo del Venezuela (Coleoptera, Carabidae, Pterostichinae). Boll. Mus. Reg. Sci. Nat. (Torino) 11: 219-237.

Moore B.P. 1977: A remarkable new genus and three new species of cavernicolous Carabidae (Coleoptera) (Zoological results of the British speleological expedition to Papua-NewGuinea 1975, 2). Int. J. Speleol. 9: 357-363.

NOONAN G.R. 1988: Faunal relationships between eastern North America and Europe as shown by insects. Mem. Entomol. Soc. Can. 144: 39-53.

ORTuÑo V.M. 1988: Importancia de los caracteres tibiales en la sistemática de Harpalidae (Col. Caraboidea). In: Act. III Congr. Ib. Entomol., León-Spain. Vol. 1. Servicio Publicaciones de Univ. de León, pp. 263-270.

ORTUÑo V.M. 1991: Estructura genital femenina de los Steropus (sensu Jeannel, 1942) ibéricos (Coleoptera, Pterostichidae). Armadura genital y complejo espermatecal. Elytron 5: 311-324.

ORTUÑo V.M. 1995: Contribución al conocimiento de la genitalia femenina en los Caraboidea (Coleoptera, Adephaga) de la Península Ibérica. $\mathrm{PhD}$ thesis. Universidad Complutense de Madrid, Madrid, 486 pp.

Ortuño V.M., Marcos J.M. \& Zabalegui I. 1999: Utilización del complejo espermatecal en la identificación de las especies ibéricas de Europhilus Chaudoir, 1859 (Col. Carabidae, Platynini). Europhilus gracilis (Sturm, 1824) nueva especie para la Península Ibérica. Boln. Asoc. Esp. Entomol. 23: $35-39$.

RodríGuez L.R., Suárez A., Barba P. \& Heredia N. 1993: Mapa Geológico de la Provincia de León. Instituto Técnico Geominero de España, León, 185 pp.

SALGADO J.M. 1979: Nueva revisión sistemática y distribución geográfica de los Bathysciinae cavernícolas de los Montes
Cantábricos (Col. Catopidae). Publ. Cuad. Espeleol. (Cantabria) 9-10: 131-138.

Salgado J.M. 1984: Estudio del Grupo Speocharis occidentalis Jeannel, 1911 (Col. Catopidae). Mém. Biospéol. 11: 257-264.

SAlgADO J.M. 1993: Los Bathysciinae (Col. Catopidae) cantábricos: Sección Speocharis. Mém. Biospéol. 20: 221-230.

Salgado J.M. 1994: Revisión del género Espanoliella Guéorguiev, 1976 (Col. Bathysciinae). Ann. Soc. Entomol. Fr. (N. S.) 30: $145-158$.

Salgado J.M. 1995: Fauna troglobia de la Cordillera del Sueve (Asturias, España). Mém. Biospéol. 22: 129-137.

Salgado J.M. \& OrtuÑo V.M. 1998: Two new cave-dwelling beetle species (Coleoptera: Carabidae: Trechinae) of the Cantabrian Karst (Spain). Coleopt. Bull. 52: 351-362.

Trajano E. 1995: Evolution of tropical troglobites: applicability of the model of quaternary climatic fluctuations. Mém. Biospéol. 22: 203-209.

UÉNO S.I. 1952: On a cave-dwelling sphodrid found in Japan (Coleoptera, Harpalidae). Mushi (Fukuoka) 24: 17-19.

UÉNo S.I. 1955: New cave-dwelling Anchomenids of Japan. Opusc. Entomol. 20: 56-64.

UÉnO S.I. 1993: Discovery of a highly modified species of Jujiroa (Coleoptera, Carabidae) on the Japan Sea side of Central Honshu, Japan. Elytra (Tokyo) 21: 329-335.

UÉno S. I. \& SAIto A. 1991: Occurrence of Jujiroa (Coleoptera, Carabidae) on the high mountains of Taiwan. J. Speleol. Soc. Japan 16: 1-28.

Vigna-Taglianti A. \& Franzini G. 1976: Osservazioni su Agelaea fulva Gené (Coleoptera, Carabidae). Fragm. Entomol. 12: $273-283$.

Whitehead D.R. 1973: Annotated key to Platynus, including Mexisphodrus and most "Colpodes", so far described from North America including Mexico (Coleoptera: Carabidae: Agonini). Quaest. Entomol. 9: 173-217.

Received July 29, 1999; accepted April 5, 2000 